\title{
Polyphasic study of Zymomonas mobilis strains revealing the existence of a novel subspecies Z. mobilis subsp. francensis subsp. nov., isolated from French cider
}

\author{
Correspondence \\ Monika Coton \\ mcoton@adrianie.org
}

\author{
Monika Coton, ${ }^{1}$ Jean-Marie Laplace, ${ }^{2}$ Yanick Auffray ${ }^{2}$ \\ and Emmanuel Coton ${ }^{1}$ \\ ${ }^{1}$ ADRIA NORMANDIE, bvd du 13 juin 1944, 14310 Villers-Bocage, France \\ ${ }^{2}$ USC-INRA Laboratoire de Microbiologie de I'Environnement, Université de Caen, Esplanade \\ de la paix, 14000 Caen, France
}

\begin{abstract}
Zymomonas mobilis strains recently isolated from French 'framboisé' ciders were compared with collection strains of the two defined subspecies, Z. mobilis subsp. mobilis and Z. mobilis subsp. pomaceae, using a polyphasic approach. Six strains isolated from six different regions of France were compared with three strains of $Z$. mobilis subsp. mobilis, including the type strain LMG $404^{\top}$, and four strains of $Z$. mobilis subsp. pomaceae, including the type strain LMG $448^{\top}$, using phenotypic and genotypic methods. For phenotypic characterization, both physiological tests and SDS-PAGE protein profiles revealed significant differences between the two known subspecies and the French isolates; three distinct groups were observed. These findings were further confirmed by random amplified polymorphic DNA and repetitive extragenic palindromic-PCR genotyping methods in which the French isolates were clearly distinguished from the other two subspecies. Sequence analysis of a fragment ranging from 604 to 617 nucleotides corresponding to the 16S-23S rRNA gene intergenic spacer region (ISR), a 592 nucleotide HSP60 gene fragment and a 1044 nucleotide gyrB gene fragment confirmed the presence of three distinct groups. The French strains exhibited almost $94 \%$ similarity to the ISR, $90 \%$ to HSP60 and $86 \%$ to gyrB sequences of the three collection strains of $Z$. mobilis subsp. mobilis and 87,84 and $80 \%$ sequence similarity, respectively, was observed with the four $Z$. mobilis subsp. pomaceae strains. Based on both the phenotypic and genotypic results, the French strains are proposed to represent a novel subspecies, Zymomonas mobilis subsp. francensis subsp. nov. Strain AN0101 ${ }^{\top}\left(=\right.$ LMG $22974^{\top}=$ CIP $\left.108684^{\top}\right)$ was designated as the type strain.
\end{abstract}

Zymomonas mobilis, a bacterium isolated from various alcoholic beverages, can be considered as either a necessary

Published online ahead of print on 9 September 2005 as DOI 10.1099/ijs.0.63732-0.

Abbreviations: HSP, heat-shock protein; ISR, intergenic spacer region; RAPD, random amplified polymorphic DNA, REP-PCR, repetitive extragenic palindromic-PCR.

The GenBank/EMBL/DDBJ accession numbers for the 16S-23S ISR sequences of Zymomonas mobilis strains LMG 404', LMG 445, AN0101', AN0102 and LMG $448^{\top}$ are AY940084-AY940087, respectively. Those of the partial HSP60 gene sequences of strains LMG 404 ${ }^{\top}$, LMG 445, LMG 448', LMG 5993 and AN0101' are AY940079-AY940083, respectively, and those of the gyrB gene sequences for strains LMG 404 ${ }^{\top}$, LMG 445, LMG $448^{\top}$ and AN0101 ${ }^{\top}$ are AY940075-AY940078, respectively.

Figures showing the results of SDS-PAGE analysis and phylogenetic trees generated from the ISR, HSP60 and gyrB gene sequences are available as supplementary material in IJSEM Online. flora in natural fermentations (agave, palm sap) and in bioreactors (ethanol, acetaldehyde production) or as a spoilage bacterium (ciders, beers and perries) (Swings \& De Ley, 1977; Buchholz et al., 1987; Miyake \& Shibamoto, 1993; O'Mullan et al., 1995; Jespersen \& Jakobsen, 1996; Coton \& Coton, 2003; Herrero et al., 2003). In 1977, based on phenotypic and genetic data, Swings and De Ley concluded that $Z$. mobilis was the only species in the genus and that two subspecies existed: $Z$. mobilis subsp. mobilis and $Z$. mobilis subsp. pomaceae (Swings \& De Ley, 1977).

In a recent study, an amplified rDNA restriction analysis (ARDRA) method was developed to identify strains of $Z$. mobilis isolated from French 'framboisé' spoiled ciders at the subspecies level (Coton \& Coton, 2003; Coton et al., 2005). Consistent differences were observed in the 16S rRNA gene sequences of these French isolates in comparison with the two previously described subspecies, Z. mobilis subsp. mobilis and Z. mobilis subsp. pomaceae (previously isolated 
from English spoiled ciders). These genetic differences raised questions about the taxonomy of this species and the French strains were considered to be part of a new genomovar within $Z$. mobilis subsp. pomaceae. In this paper, the taxonomical position of these French isolates was studied using a polyphasic approach.

Cultures of $Z$. mobilis were obtained from the DSMZ, $Z$. mobilis subsp. mobilis DSM $424^{\mathrm{T}}$ and DSM 3580 , or from the Belgian Coordinated Cultures of Microorganisms (BCCM), Z. mobilis subsp. mobilis LMG $404^{\mathrm{T}}$, LMG 445 and LMG 429 and $Z$. mobilis subsp. pomaceae LMG $448^{\mathrm{T}}$, LMG 450, LMG 451 and LMG 5993. Strain AN0101 ${ }^{\mathrm{T}}\left(=\mathrm{LMG} 22974^{\mathrm{T}}=\mathrm{CIP}\right.$ $108684^{\mathrm{T}}$ ) was designated as the type strain of the novel subspecies $Z$. mobilis subsp. francensis described in this study. Other strains (AN0102, AN0108, AN0202, AN0205 and AN0206) were part of the ADRIA NORMANDIE collection isolated from 'framboisé' spoiled ciders from different regions of France over the past 4 years. All strains were grown in either liquid medium (20 g glucose $\mathrm{l}^{-1}$ and $5 \mathrm{~g}$ yeast extract $1^{-1}$ ) overnight or anaerobically on zymomonads-pimaricine (ZP) agar (Coton \& Coton, 2003) for 5 days at $30^{\circ} \mathrm{C}$.

Morphological, physiological and biochemical characterizations of the French cider strains were performed as described by Swings \& De Ley (1977) unless otherwise stated. All strains had Gram-negative, rod-shaped cells arranged singly or in pairs. Isolated colonies appeared white- to cream-coloured, brilliant, regularly edged and had a characteristic central peak. Motility was observed using phasecontrast microscopy for all French isolates after 5 days incubation under anaerobic conditions at $30^{\circ} \mathrm{C}$. One to two polar flagella were observed using the staining method described by Heimbrook et al. (1989). Cells were catalasepositive and oxidase-negative. Strains were tested for carbohydrate fermentation abilities using the API $50 \mathrm{CHE}$ and API 20E systems (bioMérieux). All strains were negative for urease, gelatinase, $\mathrm{H}_{2} \mathrm{~S}$, lysine decarboxylase and ornithine decarboxylase. The Voges-Proskauer reaction (acetoin formation) was weak or negative and nitrates were not reduced. Two strains were arginine dihydrolase positive. All strains metabolized glucose, fructose and sucrose; assimilation of other substrates (galactose, D-mannose, mannitol, D-raffinose, gluconate and 5-ketogluconate) was weak and strain-dependent. Growth was also observed in liquid medium supplemented with $5 \%$ ethanol and from $\mathrm{pH} 3.5$ to $7 \cdot 5$. All strains were able to grow to stationary phase in the presence of 20 and $25 \%(\mathrm{w} / \mathrm{v})$ glucose after 2 and 6-14 days (depending on the studied strain), respectively. No growth was observed at $40 \%(\mathrm{w} / \mathrm{v})$ glucose after 20 days or in $1 \%$ $(\mathrm{w} / \mathrm{v})$ peptone broth after $72 \mathrm{~h}$.

Under the growth conditions described by Swings \& De Ley (1977) for differentiation of subspecies $\left(36^{\circ} \mathrm{C}, 0.5 \% \mathrm{NaCl}\right.$ and $0 \cdot 2 \%$ bile salts) as well as in a medium containing $100 \mathrm{~g}$ sucrose $1^{-1}$ as a sole carbon source and 5 g yeast extract $\mathrm{l}^{-1}$ (Skotnicki et al., 1981), phenotypic differences were observed. All tests showed a clear distinction between $Z$. mobilis subsp. pomaceae strains and $Z$. mobilis subsp. mobilis strains. However, in the presence of $\mathrm{NaCl}$, bile salts and at $36^{\circ} \mathrm{C}$, the French isolates showed very similar growth patterns to Z. mobilis subsp. pomaceae strains (no or slight growth). In the presence of $100 \mathrm{~g}$ sucrose $\mathrm{l}^{-1}$, the strains behaved like Z. mobilis subsp. mobilis strains (normal growth). Thus, these physiological tests enabled three groups to be distinguished. Similar phenotypic characteristics were observed for the French strains and the two known subspecies, showing that they are strongly related phenotypically to both subspecies and not only to $Z$. mobilis subsp. pomaceae as was previously observed based on phenotypic data (Coton \& Coton, 2003; Coton et al., 2005).

To study the phenotypic differences observed between the three groups further, SDS-PAGE was performed in triplicate using whole-cell protein extracts obtained from overnight cultures. Cultures were grown to stationary phase, $10 \mathrm{ml}$ was centrifuged at 5000 r.p.m. and the cell pellet was resuspended in $25 \mathrm{mM}$ Tris buffer. An equivalent volume of glass beads was added to each sample and the mixture was vortexed in a Retsch MM20 bead beater (Retsch) for $3 \mathrm{~min}$ at maximum speed followed by $3 \mathrm{~min}$ on ice. This step was repeated twice. The mixture was then centrifuged at 12000 r.p.m. for $10 \mathrm{~min}$ and the supernatant was transferred to a new tube. The Bradford assay was used to determine protein concentrations and $12 \%$ SDS-PAGE gels were used for migration $(80 \mathrm{~V}$ for $1.5 \mathrm{~h}$ ) of the protein extracts using a Mini Protean system (Bio-Rad) and stained with Coomassie blue. Comparison of the gel lanes showed that three distinct groups were present, corresponding to the two known subspecies and to the French isolates (see Supplementary Fig. S1 in IJSEM Online). As whole-cell extracts were used, a large number of bands was observed corresponding to soluble proteins present in the bacteria; however, certain zones were clearly characteristic. For $Z$. mobilis subsp. mobilis, as well as for the French isolates, very few bands were observed just above $20 \mathrm{kDa}$, whereas this zone contained two distinct bands for the $Z$. mobilis subsp. pomaceae group. Furthermore, just below $20 \mathrm{kDa}$, the $Z$. mobilis subsp. pomaceae group was lacking two major bands that were present distinctly in the other two groups. For the French strains, a distinct banding pattern was observed around $25 \mathrm{kDa}$ in comparison with the two other subspecies. Other distinct differences in protein profiles were also observed amongst the three groups near 37 and $50 \mathrm{kDa}$. This phenotypic characterization confirmed the findings that all the French strains are phenotypically related to each other, but also clearly demonstrated significant differences between the three groups. These results were confirmed for all other SDS-PAGE gels and all strains gave the same banding patterns on each gel that was run (data not shown).

For genetic characterization, genomic DNA was purified using the GenElute bacterial genomic DNA extraction kit (Sigma) according to the manufacturer's instructions. The concentration of purified DNA was determined using a spectrophotometer (SmartSpec 3000; Bio-Rad). Both random amplified polymorphic DNA (RAPD) analysis 
$\begin{array}{lllllllll}20 & 30 & 40 & 50 & 60 & 70 & 80 & 90 & 100\end{array}$

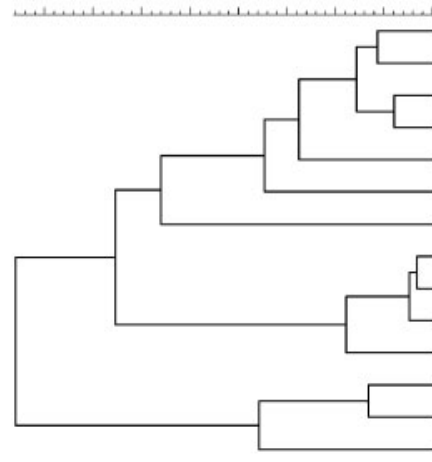

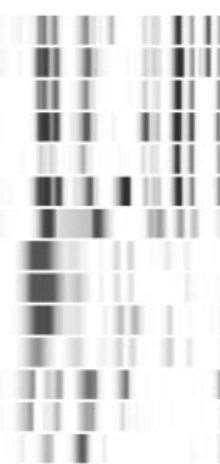

Z. mobilis francensis

Z. mobilis francensis

Z. mobilis francensis

Z. mobilis francensis

Z. mobilis francensis

Z. mobilis francensis

Z. mobilis francensis

Z. mobilis pomaceae

Z. mobilis pomaceae

z. mobilis pomaceae

Z. mobilis pomaceae

I. mobilis mobilis

I. mobilis mobilis

I Z. mobilis mobilis
AN0202

AN0102

AN0108

AN0206

AN0205

AN0101 ${ }^{\top}$

AN0205

LMG 450

LMG 451

LMG $448^{\top}$

LMG 5993

LMG 429

LMG $404^{\top}$

LMG 445
Fig. 1. RAPD fingerprints produced with primer 1 for the studied strains. The tree was constructed using the Pearson correlation and UPGMA. and repetitive extragenic palindromic-PCR (REP-PCR) were performed on the extracted DNA samples. All PCR products were separated on a $2 \%(\mathrm{w} / \mathrm{v})$ agarose gel and visualized by ethidium bromide staining using GelDoc 2000 (Bio-Rad). Analysis of the banding patterns was performed using the BIONUMERICS program (Applied Maths).

To study strain biodiversity, genomic fingerprints of the French isolates and collection strains were obtained by RAPD analysis using the Ready-to-go RAPD analysis kit (Amersham) according to the manufacturer's instructions with $50 \mathrm{ng}$ purified genomic DNA and primer 1 (Fig. 1). Analysis of the banding patterns showed that the strains clustered into four well-defined groups that clearly separated $Z$. mobilis subsp. mobilis strains into two subgroups that were different from both of the $Z$. mobilis subsp. pomaceae strains and from the French strains. Few common bands were observed between these clusters. Within the fourth group, comprising the French strains, nine common bands were observed between strains isolated from different ciderproducing regions. However, some bands allowed for subtyping of these strains. This result indicates that the French strains are closely related, but demonstrate strain biodiversity. For the Z. mobilis subsp. mobilis strains, the two subgroups consisted of strains LMG 429 and LMG $404^{\mathrm{T}}$ in the first group and strain LMG 445 in the second. The presence of two subgroups is in accordance with observations made by Swings \& De Ley (1977) based on genome DNA relatedness. They stated that two subgroups of almost identical $Z$. mobilis subsp. mobilis strains coexisted and that the first group corresponded to 28 Zaïrese palm wine strains, including LMG 445, and that the second group corresponded to three Zaïrese palm wine strains, four infected British beer strains (including LMG 429) and one strain from Mexican pulque (LMG $404^{\mathrm{T}}$ ).

To study genomic differences further, REP-PCR was performed according to Versalovic et al. (1991) using either the BOX1A primer or the primer pair ERIC1R/ERIC2 in the presence of approximately $50 \mathrm{ng}$ purified genomic DNA. Banding patterns were analysed and revealed the presence of four distinct clusters (Fig. 2). Two clusters corresponded to $Z$. mobilis subsp. mobilis strains, one to $Z$. mobilis subsp. pomaceae strains and the fourth to the French isolates. For the two $Z$. mobilis subsp. mobilis clusters, they again corresponded to LMG 429/LMG $404^{\mathrm{T}}$ and to LMG 445.

In general, within each of the four clusters, all banding patterns were similar and therefore did not allow for strainspecific fingerprinting. On the other hand, this technique allowed for analysis below the species level and clearly showed that the French strains belong to a distinct group. As with the RAPD analysis, only a few common bands were observed between groups, although within each cluster up to 15 common bands were present.

Comparison of REP-PCR and RAPD showed that RAPD was a more suitable molecular tool to study biodiversity at the strain level; however, both techniques were able to generate genomic fingerprints below the species level, making them suitable to study taxonomy and to obtain rapid identification of isolates.

To determine the phylogenetic relatedness of the strains studied, the 16S-23S rRNA gene intergenic spacer region

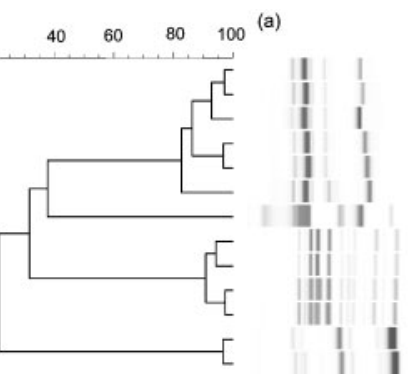

(b)

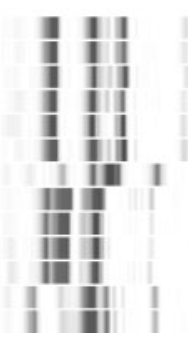

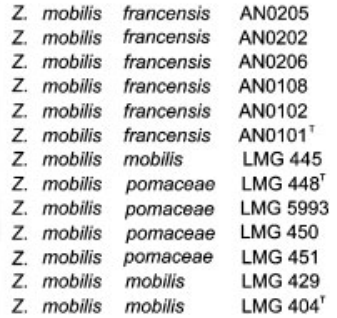

Fig. 2. REP-PCR fingerprints produced with the ERIC1/ERIC2 primer pair (a) or the BOX primer (b) for the studied strains. The tree was constructed using the Pearson correlation and UPGMA. 
(ISR), as well as housekeeping gene sequences [60 kDa heatshock protein (HSP60) and subunit B protein of DNA gyrase $(\mathrm{g} y r B)]$ were compared as recommended by Stackebrandt et al. (2002). Amplification and sequencing of the ISR was carried out using the primers Z16pr1436 (5'-GCGACTGGGGTGAAGTCG- $3^{\prime}$ ), targeting the $3^{\prime}$ end of the $16 \mathrm{~S}$ rRNA gene, and a modified universal primer named BLR187 (5'-TACTTAGATGTTTCAGTTCGC-3'), targeting the $5^{\prime}$ region of the 23S rRNA gene of eubacteria. Approximately 50 ng genomic DNA was used with the following amplification conditions: $95^{\circ} \mathrm{C}$ for $5 \mathrm{~min}, 30$ cycles of $95^{\circ} \mathrm{C}$ for $45 \mathrm{~s}$, $48^{\circ} \mathrm{C}$ for $45 \mathrm{~s}$ and $72^{\circ} \mathrm{C}$ for $1 \mathrm{~min}$, with a final extension of $72^{\circ} \mathrm{C}$ for $5 \mathrm{~min}$. For the gyrB gene, universal primer pairs for amplification (UP-1/UP-2r) and direct sequencing (UP-1S/ UP-2Sr) (Yamamoto \& Harayama, 1995) were used with the following amplification conditions: $95^{\circ} \mathrm{C}$ for $5 \mathrm{~min}, 30$ cycles of $95^{\circ} \mathrm{C}$ for $1 \mathrm{~min}, 50^{\circ} \mathrm{C}$ for $1 \mathrm{~min}$ and $72^{\circ} \mathrm{C}$ for $2 \mathrm{~min}$, with a final extension at $72^{\circ} \mathrm{C}$ for $5 \mathrm{~min}$. For HSP60, degenerate primers were created, HSP-for ( $5^{\prime}$-GACAAGTTCGAAAAYATGGG-3') and HSP-rev (5'-GGCTTYGGYGATCGYCGYAA- $3^{\prime}$ ), and used in PCR with the following amplification conditions: $95^{\circ} \mathrm{C}$ for $5 \mathrm{~min}, 30$ cycles of $95^{\circ} \mathrm{C}$ for $30 \mathrm{~s}, 52^{\circ} \mathrm{C}$ for $30 \mathrm{~s}$ and $72{ }^{\circ} \mathrm{C}$ for $1 \mathrm{~min}$, with a final extension $72{ }^{\circ} \mathrm{C}$ for $5 \mathrm{~min}$. Samples of $18 \mu \mathrm{l}$ of each PCR were run on $0.8 \%(\mathrm{w} / \mathrm{v})$ agarose gels and visualized as described above. PCR products were purified using the GenElute PCR purification kit (Sigma) according to the manufacturer's instructions and air-dried. Samples were then sent for sequencing to MWG Biotech. Sequence comparisons and analysis were performed with the BLAST (Altschul et al., 1990), CLUSTAL_X (Thompson et al., 1997) and BIONUMERICS (Applied Maths) programs.

ISR sequences, situated between the $16 \mathrm{~S}$ and $23 \mathrm{~S}$ rRNA genes and ranging from 604 to $617 \mathrm{bp}$, were determined for all of the strains studied and representative sequences were deposited in GenBank. Comparisons of the aligned sequences using a global cluster analysis, UPGMA and 1000 bootstraps showed the presence of three distinct groups corresponding to the two known subspecies and the French isolates (see Supplementary Fig. S2 in IJSEM Online). For the French strain sequences, one mismatch was observed for two of the six strains, AN0102 and AN0202, while all $Z$. mobilis subsp. pomaceae strains were $100 \%$ identical. On the other hand, within the Z. mobilis subsp. mobilis cluster, more sequence diversity was observed with up to seven mismatches being observed between the four strains studied. Sequences for the French strains showed $>94 \%$ similarity to the $Z$. mobilis subsp. mobilis, while only $\sim 87 \%$ similarity was observed to those of $Z$. mobilis subsp. pomaceae showing that the French isolates are more closely related to the $Z$. mobilis subsp. mobilis cluster at a genetic level.

Partial HSP60 gene sequences (592 bp) were obtained for all strains studied and representative sequences were deposited in GenBank. Sequence alignments showed that three distinct clusters were present (see Supplementary Fig. S3 in IJSEM Online). Complete sequence identity was found between all
French strains. Within the $Z$. mobilis subsp. pomaceae subspecies, two mismatches were observed between the LMG $448^{\mathrm{T}}$ sequence and the three other sequences. Three closely related sequence subgroups were also observed for the $Z$. mobilis subsp. mobilis cluster, merging at $>99 \%$. Overall, strong genetic discrimination was observed for these three groups, with French strains showing almost $90 \%$ similarity with the $Z$. mobilis subsp. mobilis group and almost $84 \%$ with the $Z$. mobilis subsp. pomaceae cluster.

For $g y r B, 1044$ bp sequences were obtained for all of the studied strains and representative sequences were deposited in GenBank. The resulting phylogenetic tree confirmed the above findings that the French strains are more closely related from a genomic point of view to $Z$. mobilis subsp. mobilis ( $86 \%$ similarity versus $80 \%$ with $Z$. mobilis subsp. pomaceae strains) (see Supplementary Fig. S4 in IJSEM Online). Again, strong genetic discrimination was observed using this housekeeping gene which allowed differentiation of the French isolates from the two previously described subspecies.

The use of the subspecies differentiation tests of Swings \& De Ley (1977) showed that the French isolates seemed to belong to $Z$. mobilis subsp. pomaceae. However, the addition of a growth test using sucrose as a sole carbon source showed that the French strains, which are able to utilize this sugar, are part of a distinct phenotypic group, as $Z$. mobilis subsp. pomaceae strains are unable to grow on this substrate (Skotnicki et al., 1981). SDS-PAGE protein profiles further confirmed this finding. In genotyping experiments, distinct genomic fingerprints were obtained and these confirmed that the French isolates were clearly different from the two subspecies described by Swings \& De Ley (1977). RAPD analysis enabled strain biodiversity to be observed amongst the French isolates. Previous sequence analysis based on $16 \mathrm{~S}$ rRNA genes showed more than $98 \%$ similarity between the three groups, indicating that they all belonged to the same species, Z. mobilis (Coton \& Coton, 2003; Coton et al., 2005). In this study, sequencing of more variable targets allowed for the taxonomical positioning of the French isolates. Comparison of phylogenetic trees constructed from the 16S-23S ISR, gyrB and HSP60 sequences showed that the trees were in close agreement and also revealed three distinct clusters. The sequencing analysis presented in this paper clearly allows for differentiation below the species level. As previously described (Dahllöf et al., 2000; Zhu et al., 2003), the use of housekeeping genes to study taxonomy of closely related micro-organisms is more informative than $16 \mathrm{~S}$ rRNA gene analysis. In this study, the sequencing of the gyrB and HSP60 genes proved to be a useful tool for the identification of $Z$. mobilis isolates below the species level. The results obtained in this polyphasic study proved that the isolates of $Z$. mobilis from French cider were phenotypically and genotypically different from the previously described subspecies; therefore, the French isolates are proposed as members of a novel subspecies, $Z$. mobilis subsp. francensis subsp. nov. 


\section{Emended description of $Z$. mobilis subsp. mobilis (Lindner 1928) De Ley and Swings 1976}

The description is as given by De Ley and Swings (1976) with the following modifications. Sucrose is fermented. Growth at $36^{\circ} \mathrm{C}$ and in the presence of $0.5 \% \mathrm{NaCl}$ and $0.2 \%$ bile salts.

\section{Emended description of Z. mobilis subsp. pomaceae (Millis 1956) De Ley and Swings 1976}

The description is as given by De Ley and Swings (1976) with the following modifications. Sucrose is not fermented. No growth at $36^{\circ} \mathrm{C}$, in the presence of $0.5 \% \mathrm{NaCl}$ and $0.2 \%$ bile salts.

\section{Description of Zymomonas mobilis subsp. francensis subsp. nov.}

Zymomonas mobilis subsp. francensis (fran.cen'sis. N.L. fem. adj. francensis of, or belonging to, France).

All strains meet the species description. Motile. Sucrose is fermented. No growth or slight growth at $36^{\circ} \mathrm{C}$ and in the presence of $0.5 \% \mathrm{NaCl}$; no growth in the presence of $0 \cdot 2 \%$ bile salts. All strains grow in $25 \%$ glucose, but not in $40 \%$. Urea is not hydrolysed and $\mathrm{H}_{2} \mathrm{~S}$ is not produced. Acetoin is formed weakly by some strains. Lysine- and ornithine decarboxylase-negative. Some strains are arginine dihydrolase-positive. Some strains are able to metabolize galactose (weak), D-mannose, mannitol, D-raffinose, gluconate and 5-ketogluconate.

The type strain, AN0101 ${ }^{\mathrm{T}}\left(=\mathrm{LMG} 22974^{\mathrm{T}}=\mathrm{CIP} 108684^{\mathrm{T}}\right)$, was isolated from French 'framboisé' cider.

\section{Acknowledgements}

We are grateful to Jean Euzéby for support with the nomenclature. This study was supported by funding from the Conseil Régional de BasseNormandie in the framework of Agrobio-Industries and by the European Regional Development Fund (ERDF).

\section{References}

Altschul, S. F., Gish, W., Miller, W., Myers, E. W. \& Lipman, D. J. (1990). Basic local alignment search tool. J Mol Biol 215, 403-410.

Buchholz, S. E., Dooley, M. M. \& Eveleigh, D. E. (1987). Zymomonas: an alcoholic enigma. Trends Biotechnol 5, 199-204.
Coton, E. \& Coton, M. (2003). Microbiological origin of "framboisé" in French ciders. J Inst Brew 109, 299-304.

Coton, M., Laplace, J. M. \& Coton, E. (2005). Zymomonas mobilis subspecies identification by amplified ribosomal DNA restriction analysis (ARDRA). Lett Appl Microbiol 40, 152-157.

Dahllöf, I., Baillie, H. \& Kjelleberg, S. (2000). rpoB-based microbial community analysis avoids limitations inherent in 16S rRNA gene intraspecies heterogeneity. Appl Environ Microbiol 66, 3376-3380.

De Ley, J. \& Swings, J. (1976). Phenotypic description, numerical analysis and a proposal for an improved taxonomy and nomenclature of the genus Zymomonas Kluyver and van Niel 1936. Int J Syst Bacteriol 26, 146-157.

Heimbrook, M. E., Wang, W. L. \& Campbell, G. (1989). Staining bacterial flagella easily. J Clin Microbiol 27, 2612-2615.

Herrero, M., Garcia, L. A. \& Diaz, M. (2003). The effect of $\mathrm{SO}_{2}$ on the production of ethanol, acetaldehyde, organic acids, and flavor volatiles during industrial cider fermentation. J Agric Food Chem 51, 3455-3459.

Jespersen, L. \& Jakobsen, M. (1996). Specific spoilage organisms in breweries and laboratory media for their detection. Int $J$ Food Microbiol 33, 139-155.

Miyake, T. \& Shibamoto, T. (1993). Quantitative analysis of acetaldehyde in foods and beverages. J Agric Food Chem 41, 1968-1970.

O'Mullan, P. J., Buchholz, S. E., Chase T, Jr \& Eveleigh, D. E. (1995). Roles of alcohol dehydrogenases of Zymomonas mobilis (ZADH): characterization of a ZADH-2-negative mutant. Appl Microbiol Biotechnol 43, 675-678.

Skotnicki, M. L., Lee, K. J., Tribe, D. E. \& Rogers, P. L. (1981). Comparison of ethanol production by different Zymomonas strains. Appl Environ Microbiol 41, 889-893.

Stackebrandt, E., Frederiksen, W., Garrity, G. M. \& 10 other authors (2002). Report of the ad hoc committee for the re-evaluation of the species definition in bacteriology. Int J Syst Evol Microbiol 52, 1043-1047.

Swings, J. \& De Ley, J. (1977). The biology of Zymomonas. Bacteriol Rev 41, 1-46.

Thompson, J. D., Gibson, T. J., Plewniak, F., Jeanmougin, F. \& Higgins, D. G. (1997). The CLUSTAL_X windows interface: flexible strategies for multiple sequence alignment aided by quality analysis tools. Nucleic Acids Res 25, 4876-4882.

Versalovic, J., Koeuth, T. \& Lupski, J. R. (1991). Distribution of repetitive DNA sequences in eubacteria and application to fingerprinting of bacterial genomes. Nucleic Acids Res 19, 6823-6831.

Yamamoto, S. \& Harayama, S. (1995). PCR amplification and direct sequencing of gyrB genes with universal primers and their application to the detection and taxonomic analysis of Pseudomonas putida strains. Appl Environ Microbiol 61, 1104-1109.

Zhu, L., Li, W. \& Dong, X. (2003). Species identification of genus Bifidobacterium based on partial HSP60 gene sequences and proposal of Bifidobacterium thermacidophilum subsp. porcinum subsp. nov. Int J Syst Evol Microbiol 53, 1619-1623. 